\title{
Pelatihan Penelitian Tindakan Kelas (PTK) Bagi Guru SMAN Panarukan Situbondo
}

\author{
*Sri Astutik1, Subiki², Singgih Bektiarso ${ }^{3}$ \\ 1,2,3 Universitas Jember, Jember, Indonesia
}

\begin{tabular}{|c|c|}
\hline (A) Check for updates open 0 access @ & DOI: https://doi.org/10.53621/jippmas.v1i1.5 \\
\hline Informasi Artikel & ABSTRAK \\
\hline $\begin{array}{l}\text { Riwayat Artikel: } \\
\text { Diterima: } 29 \text { Juni } 2021 \\
\text { Revisi Akhir: } 29 \text { Juni } 2021 \\
\text { Disetujui: July } 30 \text { Juni } 2021 \\
\text { Terbit: } 30 \text { Juni } 2021\end{array}$ & \multirow{3}{*}{$\begin{array}{l}\text { Salah satu upaya yang dapat dilakukan untuk meningkatkan keterampilan } \\
\text { guru dalam mengimplementasikan PTK dan menyusun hasil penelitian PTK } \\
\text { adalah dengan mengadakan pelatihan. Tujuan kegiatan pengabdian } \\
\text { masyarakat ini adalah meningkatkan kualitas pembelajaran dan penilaian } \\
\text { hasil belajar seiring dengan meningkatnya keterampilan guru dalam } \\
\text { mengimplementasikan PTK dan menyusun hasil penelitian PTK serta terjalin } \\
\text { kerjasama yang baik antara FKIP dengan khalayak sasaran. Metode yang } \\
\text { digunakan dalam kegiatan pelatihan adalah metode ceramah, metode } \\
\text { diskusi, dan metode praktik dalam mengimplementasikan dan menyusun } \\
\text { hasil penelitian PTK. Khalayak sasaran yang menjadi objek dari kegiatan } \\
\text { pengabdian masyarakat ini adalah guru SMAN Panarukan Situbondo } \\
\text { sebanyak } 41 \text { orang guru. Hasil yang diperoleh dari kegiatan pengabdian ini } \\
\text { adalah meningkatnya kemampuan guru dalam mengimplementasikan PTK } \\
\text { dan menyusun hasil penelitian PTK sehingga memberikan dampak terhadap } \\
\text { kinerja guru dan proses belajar mengajar. }\end{array}$} \\
\hline $\begin{array}{l}\text { Kata Kunci: } \\
\text { Guru SMA } \\
\text { PTK } \\
\text { Pelatihan }\end{array}$ & \\
\hline 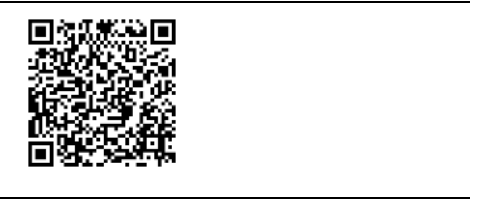 & \\
\hline
\end{tabular}

\section{PENDAHULUAN}

Penelitian tindakan dalam bidang pendidikan dipandang sebagai upaya perubahan dalam praktik pendidikan dengan cara melibatkan guru. Guru yang bekerja sama dengan peneliti dalam mengklarifikasi problem yang dihadapi dan berdiskusi tentang tindakan yang dilakukan akan mengakibatkan adanya perubahan sikap dan tingkah laku. Penelitian Tindakan Kelas (PTK) dalam pendidikan dapat dilakukan oleh guru secara individual untuk kepentingan perbaikan pembelajaran di kelas yang menjadi tanggung jawabnya atau dapat dilakukan guru secara kelompok dalam satu mata pelajaran untuk perbaikan pembelajaran disemua kelas atau semua guru disuatu sekolah untuk memperbaiki keadaan sekolah. Oleh karena itu, para guru haruslah mampu melaksanakan PTK dan mampu membuat laporan PTK.

PTK merupakan alternatif yang lebih sesuai bagi para guru dibandingkan jenis penelitian lain. Namun demikian Hopkins lebih suka menggunakan istilah penelitian kelas dari pada penelitian tindakan. Menurut Hopkins (1993) ada enam prinsip PTK, yaitu (1) Pekerjaan utama guru adalah mengajar, dan apapun metode penelitiannya seharusnya tidak mengganggu komitmen mengajarnya; (2) Metode pengumpulan data yang digunakan tidak terlalu membutuhkan waktu yang banyak bagi guru; (3) Metodologi yang digunakan harus reliabel yang memungkinkan guru merumuskan hipotesis dengan meyakinkan dan mengembangkan strategi yang dapat diterapkan pada situasi kelas. PTK tidak dimaksudkan untuk menarik kesimpulan yang dapat digeneralisasikan. Oleh karena itu dalam pengambilan sampel dan penggunaan analisis statistik tidak dituntut secara ketat; (4) Masalah penelitian yang diselesaikan oleh guru seharusnya merupakan masalah yang guru sendiri memiliki komitmen terhadapnya dan dapat diselesaikan oleh guru. Kebermaknaan masalah bukan terletak pada kompleks dan rumitnya masalah, tetapi pada acuan perbaikan dan peningkatan keefektifan tugas guru 
sebagai pengajar; (5) Penyelenggaraan PTK harus mengacu kepada kebutuhan guru untuk menaruh perhatian terhadap prosedur etika di lingkungan kerjanya; (6) Sejauh mungkin PTK mengadopsi classroom exeeding perspektif. Maksudnya adalah bahwa semua anggota secara aktif membangun dan memiliki visi yang sama terhadap tujuan utama mereka. Guru yang bekerja sama dalam PTK meningkatkan fokus penelitian terhadap prioritas sekolah secara keseluruhan.

PTK adalah Penelitian Tindakan Kelas yang harus dilaksanakan oleh guru sebagai bentuk peningkatan kompetensi guru terhadap peningkatan kualitas proses pembelajaran di sekolah dan pengembangan dunia pendidikan secara umum. PTK dirancang menggunakan empat siklus, perencanaan (planning), tindakan (action), pengamatan (observation) dan refleksi (reflection). Hasil Penelitian Tindakan Kelas atau berupa tinjauan/gagasan ilmiah yang ditulis berdasar pada pengalaman dan sesuai dengan tugas pokok serta fungsi guru. Laporan hasil penelitian tindakan kelas adalah karya tulis ilmiah berisi laporan hasil penelitian yang dilakukan guru pada bidang pendidikan yang telah dilaksanakan guru dan sesuai dengan tupoksinya, antara lain dapat berupa laporan Penelitian Tindakan Kelas.

SMA N Panarukan Situbondo merupakan salah satu lembaga pendidikan formal di bawah Kementerian Pendidikan dan Kebudayaan yang ada di Kabupaten Situbondo. Tuntutan perkembangan global mendorong para guru untuk meningkatkan kompetensinya, termasuk dalam meneliti dan melaporkan hasil penelitian. Keterampilan merancang, mengimplementasikan, mengobservasi dan merefleksi serta melaksanakan penelitian memerlukan sebuah latihan yang terus-menerus agar mampu mengkomunikasikan hasil penelitian yang telah dilakukan. Kondisi yang ada menunjukkan bahwa kemampuan guru dalam mengembangkan penelitian tindakan kelas masih belum memadai serta masih sedikit guru yang melakukan penelitian tindakan kelas sehingga perlu adanya upaya peningkatan keterampilan dalam merancang dan menyusun laporan penelitian tindakan kelas.

Berdasarkan uraian tersebut, maka diperlukan sebuah upaya meningkatkan kemampuan guru dalam memahami, merancang, mengimplementasikan, mengamati dan merefleksi serta menyusun laporan penelitian. Peningkatan kemampuan yang dimaksud dapat diperoleh guru melalui kegiatan pelatihan pembuatan dan pelaporan Penelitian Tindakan Kelas .

\section{PERMASALAHAN}

Berdasarkan analisis situasi dan permasalahan yang ada, tim pengusul dan mitra telah berdiskusi dan sepakat untuk membuat skala prioritas permasalahan-permasalahan yang akan diselesaikan, meliputi:

1. Bagaimana meningkatkan wawasan dan pemahaman guru berkaitan dengan penyusunan penelitian tindakan kelas?

2. Bagaimana guru dapat mengimplementasikan penelitian tindakan kelas?

3. Bagaimana guru dapat menyusun dan membuat laporan penelitian tindakan kelas?

\section{METODE PELAKSANAAN}

Kegiatan pengabdian masyarakat ini dilakukan di SMAN Panarukan Situbondo selama 6 bulan. Lokasi SMAN Panarukan Situbondo berada diluar kabupaten Jember namun begitu akses lokasi mitra dari Universitas Jember cukup mudah karena banyak alternatif jalan yang dapat dilalui menuju ke lokasi. 
Kegiatan pengabdian masyarakat dalam bentuk pelatihan berlangsung di Aula SMAN Panarukan Situbondo. Selama pelaksanaan kegiatan pengabdian masyarakat, kegiatan dibagi menjadi dua bagian umum, yaitu kegiatan pemaparan tentang hakikat penelitian tindakan kelas, pengertian penelitian tindakan kelas, pelaksanaan penelitian tindakan kelas yang terdiri dari perencanaan (planning), pelaksanaan (action), pengamatan (observation) dan refleksi (reflection), dan sistematika penelitian tindakan kelas. Selanjutnya dilakukan kegiatan latihan menyusun penelitian tindakan kelas dan cara melaksanakan penelitian tindakan kelas serta menyusun hasil laporan penelitian. Kegiatan latihan ini berguna untuk memberikan pengalaman secara langsung kepada peserta pelatihan.

Sesuai dengan permasalahan yang ada, khalayak sasaran dalam kegiatan pengabdian kepada masyarakat ini adalah guru-guru di SMAN Panarukan Situbondo. Peserta pelatihan ini sebanyak 41 guru SMAN Panarukan Situbondo.

\section{PELAKSANAAN}

Prosedur kerja untuk mendukung metode pelaksanaan yang ditawarkan sebagai bentuk pelaksanaan program pengabdian kepada masyarakat meliputi: penyusunan perencanaan (planning), pelaksanaan (action), pengamatan (observation) dan refleksi (reflection), dan sistematika penelitian tindakan kelas, melakukan praktik mengembangkan dan menyusun penelitian tindakan kelas, dan diakhir dengan kegiatan evaluasi.

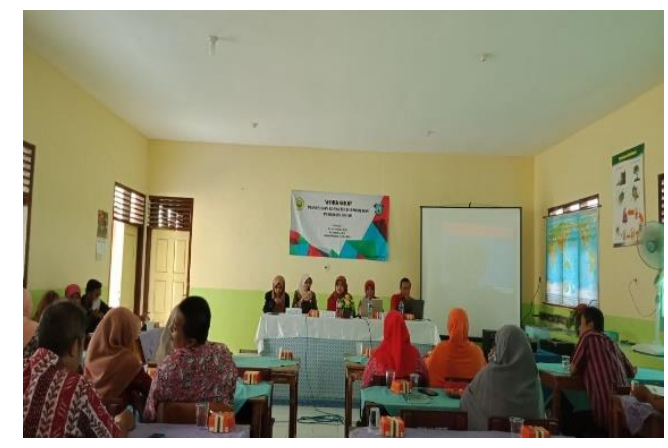

Gambar 1. Pembukaan

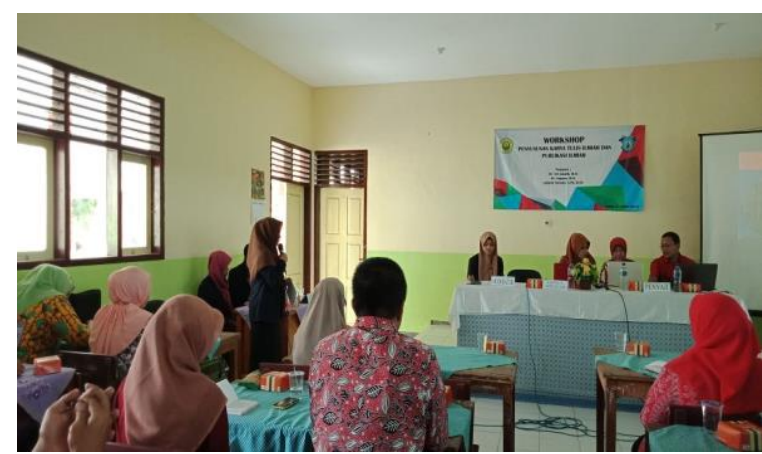

Gambar 3. Pembukaan Acara Oleh Wakasek

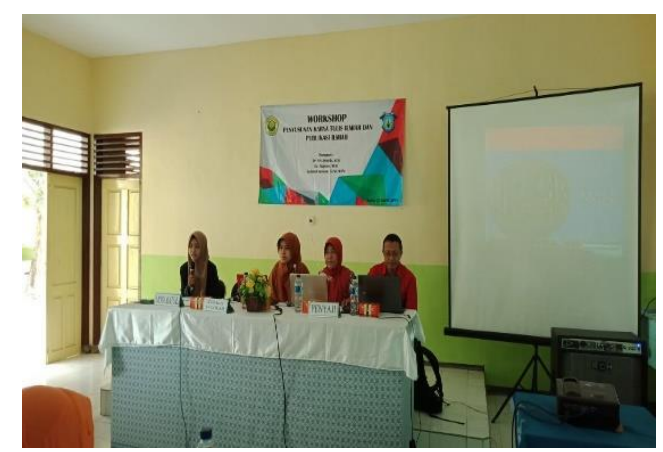

Gambar 2. Penyampaian Materi

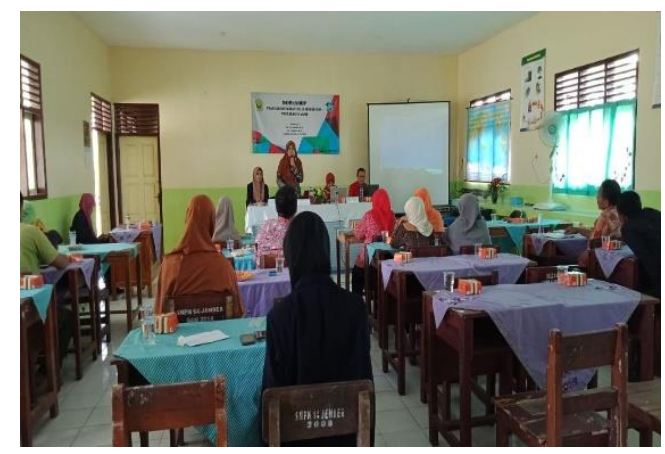

Gambar 4. Penyampaian Materi 


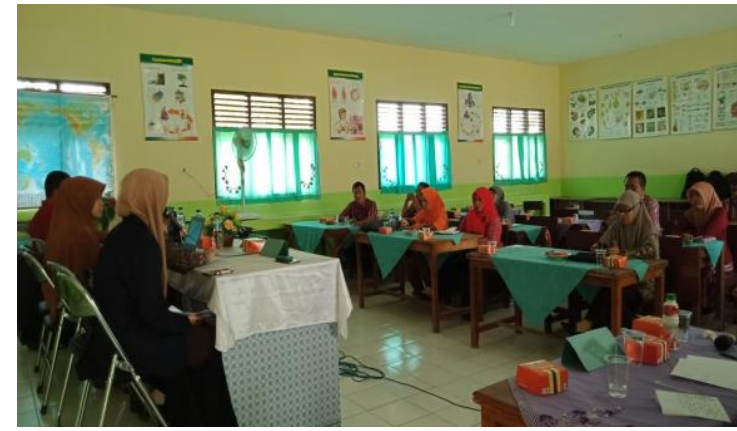

Gambar 5. Penyampaian Materi

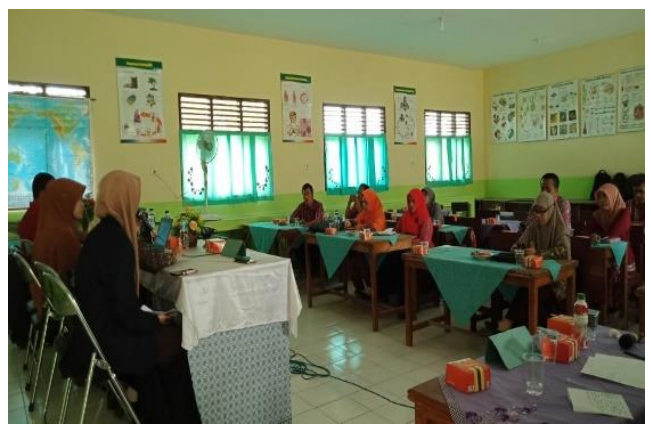

Gambar 7. Latihan Menyusun Laporan PTK

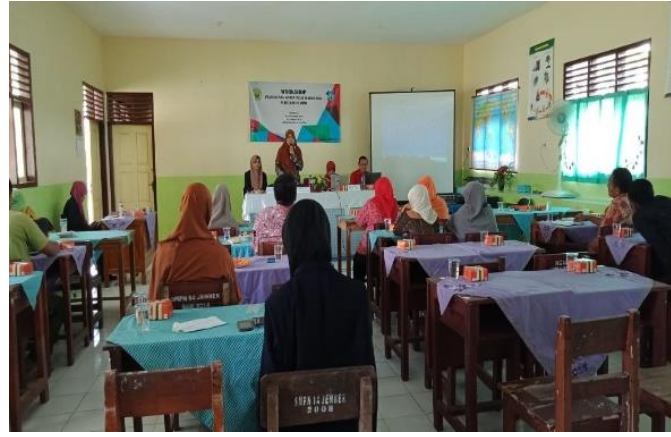

Gambar 6. Penyampaian Materi

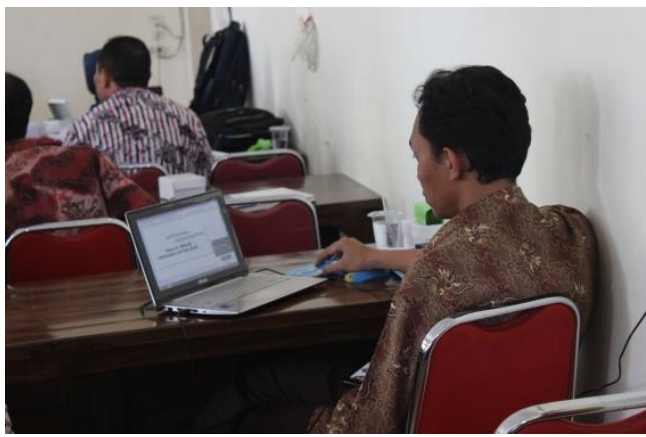

Gambar 8. Latihan menyusun Artikel

Berbagai metode digunakan dalam pelaksanaan pelatihan perancangan penelitian tindakan kelas, yaitu ceramah, diskusi, dan praktik. Metode ceramah dan diskusi digunakan untuk menjelaskan materi mengenai kemampuan menyusun penelitian tindakan kelas dalam pembelajaran dan cara menyusun laporan penelitian tindakan kelas oleh guru dilakukan di Aula SMAN Panarukan Situbondo. Metode praktik diperlukan guna untuk mengetahui seberapa jauh guru mampu merancang penelitian tindakan kelas dan menyusun laporan penelitian kelas.

\section{HASIL DAN DISKUSI}

Pelatihan diawali dengan penyajian materi tentang pengertian dan hakikat penelitian tindakan kelas. Pada sesi ini, peserta pelatihan diberi penjelasan tentang pengertian penelitian tindakan kelas, aspek-aspek penelitian tindakan kelas, tujuan dan manfaat penelitian tindakan kelas, merancang dan melaporkan hasil penelitian. Perencanaan penelitian tindakan kelas (PTK) merupakan proses pengumpulan dan pengolahan informasi penelitian bagi guru. Pelaksanaan/Tindakan merupakan proses pengimplementasian dari perencanaan. Pengamatan dilakukan di kelas dengan dibantu oleh seorang observer. Selanjutnya dilakukan evaluasi terhadap hasil pembelajaran dan hasilnya akan direfleksi untuk menentukan apakah kegiatan pembelajaran sudah tuntas atau lanjut ke siklus berikutnya. Perancangan penelitian oleh pendidik bertujuan untuk memantau dan mengevaluasi proses penelitian, menyusun rencana pelaksanaan penelitian dan penyusunan laporan penelitian. Penyusunan laporan penelitian digunakan untuk: 1) mengukur dan mengetahui pencapaian kompetensi guru; 2) memperbaiki proses pembelajaran; dan 3) menyusun laporan penelitian.

Hakikat penelitian tindakan kelas (PTK) adalah adanya tindakan yang diperlukan untuk mengatasi masalah praktis yang dihadapi guru dalam tugas kesehariannya. Dengan demikian tujuan PTK tidak hanya berusaha mengungkap penyebab dari permasalahan pembelajaran yang dihadapi guru, tetapi lebih dari itu adalah untuk 
memberikan solusi untuk mengatasi permasalahan pembelajaran yang dihadapi guru. PTK diawali dengan kesadaran adanya permasalahan yang dirasakan mengganggu dalam pelaksanaan pembelajaran dan dianggap mempengaruhi pencapaian hasil belajar siswa. Berpijak dari kesadaran adanya permasalahan yang mungkin permasalahan tersebut masih belum jelas, selanjutnya adalah menetapkan fokus permasalahan secara lebih tajam. Perumusan permasalahan yang lebih tajam dapat dilakukan dengan mendiagnosis kemungkinan penyebab munculnya permasalahan, sehingga terbuka peluang untuk menjajaki alternatif-alternatif tindakan yang diperlukan untuk mengatasi permasalahan. Alternatif untuk mengatasi permasalahan yang terbaik, selanjutnya diterjemahkan menjadi program tindakan perbaikan. Hasil tindakan perbaikan akan dinilai dan direfleksikan dengan mengacu kepada kriteria-kriteria perbaikan yang telah ditetapkan. Untuk memenuhi tujuan tersebut, maka diperlukan suatu prosedur atau desain PTK.

Sesi berikutnya diberikan penjelasan tentang prosedur penelitian. Prosedur penelitian tindakan kelas (PTK) oleh pendidik dilakukan dengan urutan: 1) menetapkan penelitian tindakan kelas yang telah disusun dan dilakukan;2) menyusun sistematika penelitian; 3) membuat artikel dari hasil penelitian; 4) melakukan analisis hasil penyusunan penelitian; 5) melakukan penilaian; 6) mengolah, menganalisis, dan menginterpretasikan hasil penelitian; 7) melaporkan hasil penelitian; dan 8) memanfaatkan laporan hasil penelitian. Penyusunan laporan penelitian yang dilakukan oleh guru selanjutnya dimasukkan pada jurnal untuk dipublikasikan.

Kegiatan selanjutnya adalah meninjau pembelajaran di kelas diantaranya adalah guru menyampaikan materi pelajaran tertentu dengan menggunakan metode mengajar yang telah direncanakan. Setelah selesai menyampaikan materi satu pokok bahasan guru memberi tes kepada siswanya dan kemudian hasil tes tersebut dianalisis untuk diketahui keberhasilan proses pembelajarannya. Hasil analisa ini digunakan untuk mengevaluasi diri apakah metode mengajar yang digunakan cocok atau tidak, atau mungkin melihat apakah butir tesnya sesuai atau tidak. Guru melakukan proses refleksi terhadap penyelenggaraan pembelajaran yang dilakukan sendiri dengan tujuan untuk memperbaiki proses pembelajaran selanjutnya. Apabila dikaitkan dengan kegiatan penelitian, maka kegiatan yang dilakukan guru tersebut adalah melakukan eksperimen, mengumpulkan data, menganalisa data dan membuat kesimpulan tentang keberhasilan pembelajarannya. Berdasarkan pada kegiatan yang dilakukan guru untuk memperbaiki proses pembelajaran yang menjadi tanggung jawabnya, maka kegiatan yang dilakukan guru tersebut merupakan bagian dari kegiatan penelitian tindakan.

Perubahan-perubahan yang dilakukan guru didasarkan pada hasil refleksi terhadap penyelenggaraan pembelajaran. Hasil refleksi yang dimaksudkan adalah analisis kritis terhadap aspek-aspek dan tahapan-tahapan proses pembelajaran yang dikelolanya. Jony (1995:5) menyatakan refleksi mengandung arti mempertanyakan pertanyaan-pertanyaan komprehensif dan mendasar yang dilakukan selama proses refleksi itu. Menanyakan apa yang sedang dikerjakan dan mengapa saya kerjakan. Dalam proses refleksi terjadi evaluasi diri, dimana guru menanyakan pertanyaan-pertanyaan yang bermuatan nilai tentang dirinya sendiri. Kesimpulan yang diperoleh dari hasil analisis kritis atau evaluasi tersebut merupakan bahan masukan untuk memperbaiki rancangan dan pelaksanaan pembelajaran selanjutnya.

Pada uraian tentang pengertian PTK tersirat bahwa tujuan dilaksanakan PTK adalah untuk perbaikan dan/atau peningkatan praktik pembelajaran secara berkesinambungan yang pada dasarnya melekat pada penunaian misi profesional kependidikan yang 
diemban oleh guru. McNiff (1992) menegaskan bahwa dasar utama bagi dilaksanakan PTK adalah untuk perbaikan. Makna perbaikan disini adalah dalam konteks proses pembelajaran khususnya dan implementasi program sekolah pada umumnya. Tujuan tersebut dapat dicapai dengan melakukan perencanaan tindakan alternatif oleh guru yang merupakan hasil dari diagnosis keadaan, kemudian dicobakan dan dievaluasi yang selanjutnya dilakukan refleksi.

Apabila perbaikan dan peningkatan layanan profesional guru dalam konteks pembelajaran dapat tercapai berkat dilakukan PTK, ada tujuan pengiring yang dapat dicapai sekaligus yaitu tumbuhkembangnya budaya meneliti dika-langan guru dan pendidik calon guru. Perlu dipahami bahwa pengembangan ilmu pengetahuan dalam arti umum yang dapat digeneralisasi bukan merupakan tujuan utama pada PTK.

Dengan tumbuhkembangnya budaya meneliti dikalangan guru secara berkesinambungan, maka manfaat utama yang dapat dipetik adalah adanya inovasi pendidikan. Pelaku inovasi pendidikan itu sendiri adalah guru yang berperan diujung tombak pelaksana lapangan. Karena guru tidak hanya sebagai pelaksana, tetapi juga sebagai pelaku inovasi pendidikan maka hal inilah yang merupakan embrio untuk tumbuhnya MPMBS yang diawali dari kelas. Untuk lebih jauh lagi guru dapat melakukan PTK untuk reformasi kurikulum. Pada gilirannya hal ini akan merupakan embrio dari pengembangan kurikulum berbasis sekolah. Apabila inovasi pembelajaran khususnya dan inovasi pendidikan umumnya bersifat bottom-up maka secara tidak langsung konsep dasar MPMBS sudah diterapkan. Dengan demikian peran sekolah bukan lagi sebagai 'unit pelaksana' pendidikan akan tetapi sebagai 'unit kerja' pendidikan.

Peserta pelatihan juga diberi penjelasan tentang Hakikat penelitian tindakan kelas (PTK) adalah adanya tindakan yang diperlukan untuk mengatasi masalah praktis yang dihadapi guru dalam tugas kesehariannya. Dengan demikian tujuan PTK tidak hanya berusaha mengungkap penyebab dari permasalahan pembelajaran yang dihadapi guru, tetapi lebih dari itu adalah untuk memberikan solusi untuk mengatasi permasalahan pembelajaran yang dihadapi guru. PTK diawali dengan kesadaran adanya permasalahan yang dirasakan mengganggu dalam pelaksanaan pembelajaran dan dianggap mempengaruhi pencapaian hasil belajar siswa. Berpijak dari kesadaran adanya permasalahan yang mungkin permasalahan tersebut masih belum jelas, selanjutnya adalah menetapkan fokus permasalahan secara lebih tajam. Perumusan permasalahan yang lebih tajam dapat dilakukan dengan mendiagnosis kemungkinan penyebab munculnya permasalahan, sehingga terbuka peluang untuk menjajaki alternatifalternatif tindakan yang diperlukan untuk mengatasi permasalahan. Alternatif untuk mengatasi permasalahan yang terbaik, selanjutnya diterjemahkan menjadi program tindakan perbaikan. Hasil tindakan perbaikan akan dinilai dan direfleksikan dengan mengacu kepada kriteria-kriteria perbaikan yang telah ditetapkan. Untuk memenuhi tujuan tersebut, maka diperlukan suatu prosedur atau desain PTK.

Desain PTK diberikan oleh Kemmis \& McTaggart (1988) menyatakan bahwa model PTK berbentuk spiral dengan masing-masing siklus terdiri dari empat tahap, yaitu perencanaan, tindakan, observasi, dan refleksi (Gambar 2). Siklus penelitian dapat direncanakan dua siklus atau lebih sesuai dengan tercapainya kriteria keberhasilan yang direncanakan. Apabila dua siklus atau lebih dan kriteria keberhasilan belum tercapai, maka guru peneliti dapat mempertim-bangkan untuk menghentikan siklusnya. Pada dasarnya tidak ada batasan sampai berapa siklus harus dilakukan, namun demikian rasa kepuasan guru peneliti juga merupakan pertimbangan untuk menetapkan banyaknya 
siklus yang dilakukan. Berdasarkan hal ini maka kriteria keberhasilan harus ditetapkan sesuai dengan kemampuan melaksanakan.

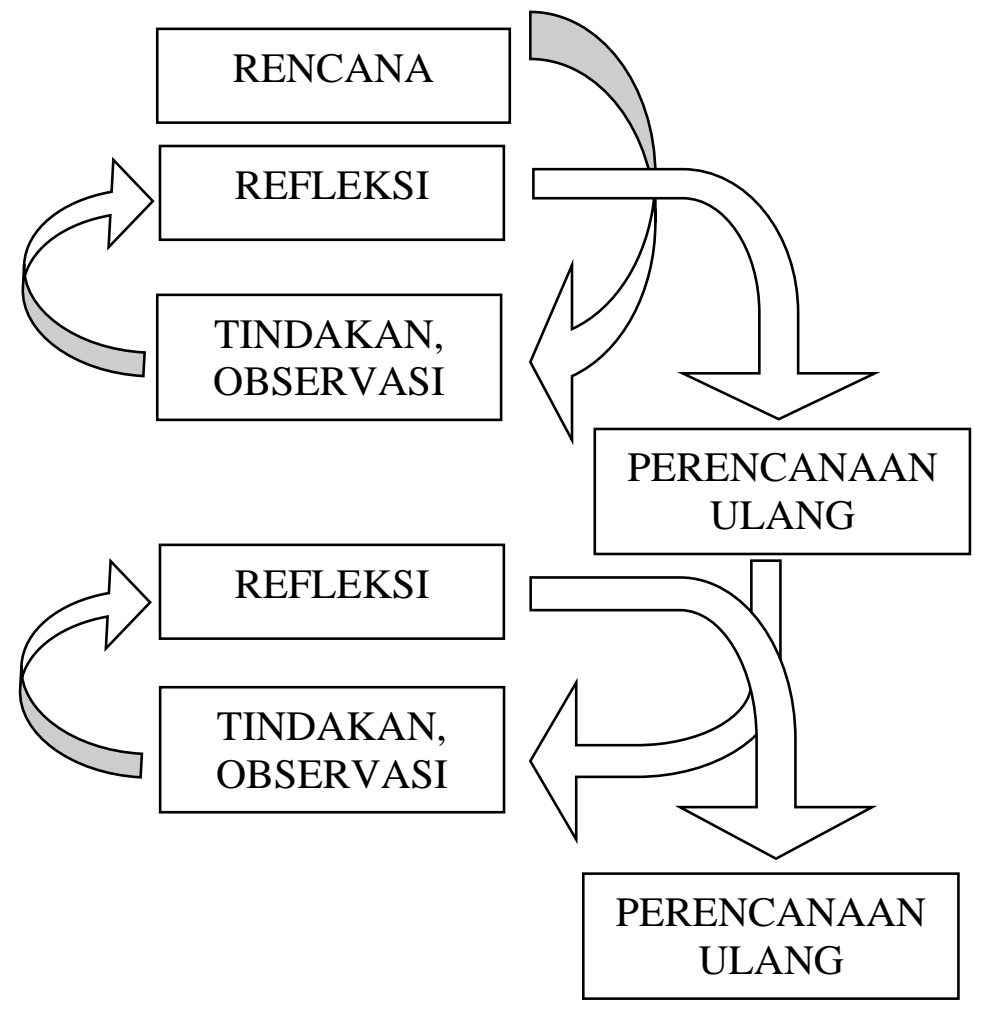

(Kemmis \& McTaggart, 1988)

\section{Gambar 2. Siklus Penelitian Tindakan Kelas}

Langkah-langkah selanjutnya adalah melihat keberhasilan suatu pembelajaran merupakan dambaan bagi setiap guru yang melakukan pembelajaran. Keberhasilan suatu tindakan perbaikan pembelajaran merupakan harapan bagi guru peneliti. Untuk melakukan tindakan perbaikan pembelajaran, guru mengharapkan suatu keberhasilan yang lebih baik dibanding-kan ketercapaian sebelumnya. Misalnya, biasanya siswa memerlukan waktu 60 menit untuk menyelesaikan satu masalah pemecahan masalah matematika, maka keberhasilan tindakan dapat ditetapkan siswa mencapai 45 menit untuk menyelesaikan satu masalah pemecahan masalah matematika. Contoh lain, pencapain keberhasilan siswa sebelumnya adalah 60\%, maka keberhasilan tindakan perbaikan dapat ditetapkan $70 \%$ atau lebih sesuai dengan harapan yang dijanjikan pada tindakan perbaikan. Apabila tindakan perbaikan menjanjikan sangat lebih baik, maka kriteria keberhasilan bisa ditetapkan lebih dari 70\%. Penetapan kriteria keberhasilan sangat tergantung pada besarnya nilai harapan tindakan perbaikan. Jadi kriteria keberhasilan dapat didasarkan pada berbagai dimensi. Misalnya, dimensi proses belajar dan dimensi hasil belajar. Dimensi proses belajar, misalnya: waktu yang diperlukan siswa belajar, frekuensi dan/atau kualitas pertanyaan siswa, kerja sama antar siswa dalam pelaksanaan tugas-tugas, jumlah dan/atau ragam sumber belajar yang dimanfaatkan oleh siswa. Dimensi hasil belajar, misalnya: prestasi akademik konvensional siswa, miskonsepsi terhadap materi belajar, jenis dan/atau mutu produk belajar yang dihasilkan siswa, perasaan ingin tahu para siswa, perasaan puas para siswa.

Setelah peserta memahami secara teoritis tentang penelitian tindakan kelas, kegiatan dilanjutkan dengan latihan menyusun persiapan penelitian. Peserta antusias untuk 
menyusunnya. Beberapa peserta yang belum memahami dan memiliki pertanyaan, langsung mengajukan pertanyaan kepada pemateri. Untuk memantau kemampuan peserta, pemateri berkeliling melihat hasil kerja peserta dan memantau perkembangan kemampuannya sambil memberi bimbingan ke peserta secara individu. Pada sesi ini, peserta juga diberi kesempatan berlatih merancang kegiatan penelitian tindakan kelas. Seluruh peserta pelatihan nampak antusias mengikuti kegiatan praktik tersebut.

Selama pelaksanaan pelatihan, beberapa peserta yang belum menguasai materi diberi kesempatan untuk mengajukan pertanyaan. Beberapa pertanyaan yang diajukan oleh peserta tentang teknis penyusunan penelitian PTK dan bagaimana cara paling mudah dalam membuat rancangan penelitian dan selanjutnya melaporkan hasil penelitian.

\section{Evaluasi Kegiatan}

Hasil yang diperoleh dari kegiatan pengabdian ini menunjukkan bahwa pelatihan penyusunan penelitian tindakan kelas dan penyusunan laporan PTK bagi guru SMAN Panarukan Situbondo berlangsung dengan lancar dan sukses. Peserta dengan antusias mengikuti seluruh acara pelatihan, termasuk kegiatan latihan menyusun dan mempraktikkan rancangan penelitian yang telah dibuat dalam kegiatan pembelajaran di kelas. Beberapa peserta masih ada yang belum menguasai seluruh materi yang dilatihkan. Hal ini menunjukkan bahwa perlu adanya pengembangan dan pemantauan terhadap kegiatan penyusunan penelitian dan pembuatan laporan penelitian.

Kemampuan yang diperoleh peserta selama pelatihan dapat dikembangkan dan diimplementasikan dalam kegiatan belajar mengajar di kelas sehingga berdampak pada efektivitas dan efisiensi pembelajaran. Selain itu rancangan penelitian dan laporan hasil penelitian yang dihasilkan oleh guru dapat digunakan sebagai bahan diskusi dan dipraktikkan dalam latihan mengajar bagi guru-guru lain dalam wadah Musyawarah Guru Mata Pelajaran (MGMP) di tingkat kabupaten. Dengan demikian citra sekolah di masyarakat akan terangkat. Selain itu para peserta perlu mendapat pelatihan lanjutan agar keterampilan mereka dalam menghasilkan alat penilaian yang komprehensif semakin terasah. Untuk pelatihan lain yang memungkinkan untuk dilakukan di waktu yang akan datang adalah pelatihan tentang publikasi ilmiah untuk seluruh aspek kognitif dan seluruh jenis pengetahuan.

\section{KESIMPULAN}

Berdasarkan hasil yang diperoleh dari kegiatan yang telah dilakukan dan berdasarkan respon yang diberikan oleh peserta pelatihan maka secara garis besar untuk kegiatan pengabdian kepada masyarakat ini dapat diambil kesimpulan sebagai berikut: (1) Guruguru SMAN Panarukan Situbondo yang mengikuti pelatihan bertambah wawasan, pengetahuan, dan keterampilannya dalam menyusun PTK dan menyusun laporan PTK; (2) Guru-guru SMAN Panarukan Situbondo yang mengikuti pelatihan bertambah pengetahuannya dalam penelitian dan penyusunan laporan penelitian yang berorientasi pada pembelajaran berpusat pada peserta didik (student center learning/SCL) dengan melakukan penelitian PTK; (3) Guru-guru SMAN Panarukan Situbondo yang mengikuti pelatihan bertambah pengetahuan dan keterampilannya dalam melaksanakan penelitian untuk disusun dalam laporan penelitian. Dari hasil kegiatan yang telah diperoleh, maka dapat diberikan saran sebagai berikut: (1) Perlu dilakukan tindak lanjut dari kegiatan ini berupa menampung ide-ide inovatif yang muncul dari peserta untuk dapat dikembangkan dan diterapkan dalam menyusun PTK dan melaporkan PTK pada semua mata pelajaran; (2) Perlu dilakukan tindak lanjut dari kegiatan ini berupa penelitian PTK 
pada semua mata pelajaran; (3) Perlu dilakukan pelatihan publikasi ilmiah pada jurnal nasional maupun internasional; (4) Perlu dilakukan kegiatan pelatihan lanjutan terutama melatih keterampilan guru dalam melakukan publikasi ilmiah yang digunakan untuk mengukur aspek afektif dan psikomotor.

\section{UCAPAN TERIMA KASIH}

Ucapan terima kasih kami sampaikan kepada Universitas Jember yang telah mendanai PKM ini.

\section{DAFTAR PUSTAKA}

Agar, M.H. (1980) The Professional Stranger: An Informal Introduction to Etnography. Orlando: Academic Press.

Elliot, J. 1991. Action Research for Educational Change. Philadelphia: Open University Press.

Gay, L.R. 1996. Educational Research: Competencies for Analysis and Application. New Jersy: Merril/Prentice Hall.

Hopkins, D. 1993. A Teacher's Guide to Classroom Research (2nd Ed.). Buckingham: Open University Press.

Jony, T.R. (Ed.). 1995. Penelitian Praktis Untuk Perbaikan Pengajaran. Jakarta: Proyek PPGSD Dirjen Dikti.

Kemmis, S. \& McTaggart, R. 1988. The Action Research Planner. Victoria: Deakin University Press.

McNiff, J. 1992. Action Research: Principles and Practice. London: Routledge, Champman and Hill Inc.

Mills, G.E. 2000. Action Research: A Guide for The Teacher Researcher. Columbus: Prentice Hall.

Rofi'uddin, A.H. 1994. Rancangan Penelitian Tindakan. Makalah disampaikan pada Lokakarya Penelitian Kualitatif Tingkat Lanjut Angkatan III, 24 Oktober - 29 Desember. Malang: Lemlit IKIP Malang.

Tim Pelatih Proyek PGSM. 1999. Penelitian Tindakan Kelas (Classroom Action Research). Jakarta: Proyek PGSM Dirjen Dikti.

\footnotetext{
* Dr. Sri Astutik, M.Si (Corresponding Author)

Universitas Jember,

Jl. Kalimantan Tegalboto No.37, Kabupaten Jember, Jawa Timur 68121, Indonesia

Email: tika.fkip@unej.ac.id

\section{Drs. Subiki, M.Kes.}

Universitas Jember,

Jl. Kalimantan Tegalboto No.37, Kabupaten Jember, Jawa Timur 68121, Indonesia

Email: subiki.fkip@unej.ac.id

Dr. Singgih Bektiarso, M.Pd.

Universitas Jember,

Jl. Kalimantan Tegalboto No.37, Kabupaten Jember, Jawa Timur 68121, Indonesia

Email: singgih.fkip@unej.ac.id
} 